\title{
OVERVIEW OF THE NEW LEGAL ERA FOR DEVELOPMENT PROJECTS IN THE NEWFOUNDLAND AND LABRADOR OFFSHORE
}

\author{
TODD STANLEY, Q.C.
}

\begin{abstract}
Petroleum projects offshore Newfoundland and Labrador continue to hold promise. The 20year history of these projects developed within a legal and regulatory context that is currently being overhauled. This article outlines key similarities among Newfoundland and Labrador's original offshore petroleum projects, describing them as projects of a legal era that is drawing to a close. The article then proceeds to recount the key features of a new legal and regulatory landscape that the up-and-coming offshore petroleum projects will face. Major elements of this new legal era include: changes in supporting legal structure, shortened lead time between discovery and development, new entrants (including increased interest from major international companies), new locations, and changes to the environmental assessment regime.
\end{abstract}

\section{TABLE OF CONTENTS}

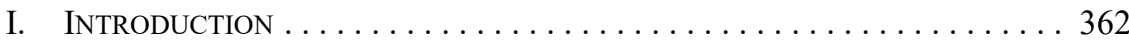

II. The EXISTING DEVELOPMENTS $\ldots \ldots \ldots$. . . . . . . . . . . . . . . . . . . 362

A. HibERNIA . . . . . . . . . . . . . . . . . . . . . . . . . . . 362

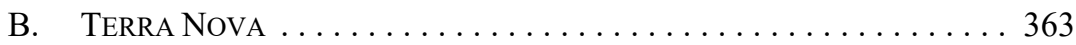

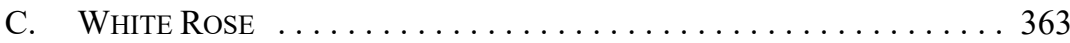

D. HeBron . . . . . . . . . . . . . . . . . . . . . . . . . . . . . 363

III. A SHARED History: ProjectS OF AN ERA . . . . . . . . . . . . . . . . 364

A. Similarity 1: The Supporting Legal Structure . . . . . . . . . . 364

B. Similarity 2: THE History of DeVElopMENT . . . . . . . . . . . . 364

C. Similarity 3: The Proponents . . . . . . . . . . . . . . . 365

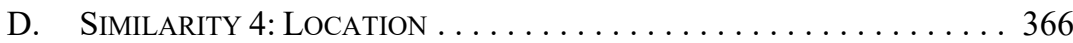

E. SIMILARITY 5: ENVIRONMENTAL ASSESSMENT . . . . . . . . . 366

F. Similarity 6: The Royalty Regime . . . . . . . . . . . . . 369

IV. A DifFERENT AND UNCERTAIN FUTURE . . . . . . . . . . . . . . . . 372

A. Difference 1: The Supporting Legal Structure . . . . . . . . 373

B. DifFERENCE 2: THE History of DEVElopMENT . . . . . . . . . . . . 375

C. Difference 3: The Proponents ... . . . . . . . . . . . 375

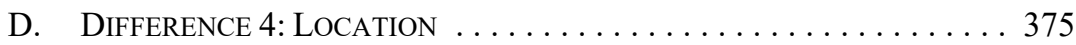

E. DifFERENCE 5: ENVIRONMENTAL ASSESSMENT . . . . . . . . . 376

F. Difference 6: The Royalty Regime . . . . . . . . . . . . . . 381

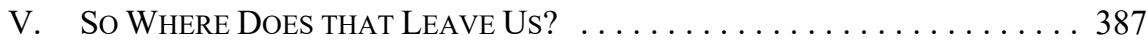

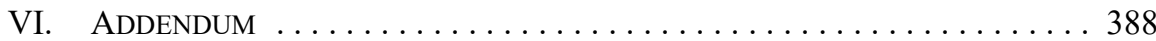

Partner at Cox \& Palmer, St. John's, Newfoundland and Labrador. Special thanks to Cox \& Palmer for the time to develop this article, as well as to Thomas Munn, Lindsey Wareham, Luke Hayden, Atanu Haldar, and Emily Hickey for their assistance in the preparation of this article. Any mistakes are my own. 


\section{INTRODUCTION}

This article will propose that we are at the beginning of a new legal era for the development of petroleum projects in the Newfoundland and Labrador offshore.

The development of producing petroleum projects offshore Newfoundland and Labrador has seen the birth of an industry in the past 20 years, if one measures from first oil at the Hibernia platform in 1997. Recent increases in interest in exploration activities indicate that this is likely not the end of the story - that there is every expectation that we will see new development projects in the offshore being proposed and moving to development in the coming years. A closer look indicates that these future projects will face a significantly different legal environment than that under which the existing projects developed. The context for development has changed both in terms of changes to the regulatory regimes which govern the economics, assessment, and approvals of such projects, as well as the introduction of entirely new legal issues. The implications of these changes, coupled with other fundamental differences in development activities, have yet to be fully realized, but they do raise the question of the degree to which the lessons learned by all parties from past developments are still applicable as the industry moves forward.

\section{The EXISTING DeVELopMentS}

An analysis of the differences facing any future development projects in the Newfoundland and Labrador offshore ${ }^{1}$ requires a review of various characteristics of the existing projects, and in particular highlighting the similarities between the four existing commercial offshore development projects: Hibernia, Terra Nova, White Rose, and Hebron. ${ }^{2}$

\section{A. Hibernia}

The Hibernia Project was the first offshore development project in the NL Offshore, and the progenitor of the industry. It was the first project to go through the development project approval process under the CNLOPB. The original discovery wells for the Hibernia field were drilled in 1979; the project commenced production in the Jeanne d'Arc Basin $300 \mathrm{~km}$ east of St. John's in November 1997. The development uses one of the largest offshore oil platforms in the world, a concrete gravity-based structure constructed in Newfoundland and Labrador. It is operated by the Hibernia Management and Development Corporation, led by ExxonMobil Canada. As of September 2019, it has produced 1.10 billion barrels of oil; ${ }^{3}$ the field is expected to have an additional life of approximately 20 years. The original project has been subject to a number of expansions as the field was developed. This has included a major expansion known as the Hibernia Southern Extension Project, which was treated as

For the purposes of this article, the term "NL Offshore" will be used in reference to the ocean area of the Canadian continental shelf surrounding Newfoundland and Labrador regulated for petroleum development by the Canada-Newfoundland and Labrador Offshore Petroleum Board (CNLOPB).

All information per the CNLOPB can be found online: $<$ cnlopb.ca/offshore/ $>$ unless otherwise noted.

CNLOPB, "Cumulative Production - Offshore Newfoundland" (24 October 2019), online: <www. cnlopb.ca/wp-content/uploads/off_prod.pdf $>$ [Cumulative Production]. 
a separate project for development approval by the CNLOPB, and has a separate royalty regime and differing equity interests from the primary development. ${ }^{4}$

\section{B. TERRA NOVA}

The second development in the offshore area, the Terra Nova Project, commenced production in January 2002. It was based off a discovery well drilled in 1984 by PetroCanada; Suncor is the project operator. It is located in the Jeanne d'Arc Basin $350 \mathrm{~km}$ from St. John's and approximately $40 \mathrm{~km}$ from the Hibernia development. Production is through the Terra Nova floating production storage and offloading vessel (FPSO), one of the largest FPSOs ever built. The FPSO is $292.2 \mathrm{~m}$ long and $45.5 \mathrm{~m}$ wide. ${ }^{5}$ As of September 2019 , it had produced 423 million barrels of oil. ${ }^{6}$ The original projected life of field was 25 years from first oil; in May 2019, Suncor announced sanction of plans to extend the FPSO to 2031 . $^{7}$

\section{White Rose}

The White Rose development is located $350 \mathrm{~km}$ east of St. John's on the northeast margin of the Jeanne d'Arc Basin. The original project commenced production in 2005, using the SeaRose FPSO. The original underlying formations were also discovered in 1984. It has undergone a number of expansions since it commenced production, with additional fields and developments produced by the SeaRose through subsea tieback structures. The two most significant expansions, the North Amethyst and South White Rose extensions, were treated as separate development projects for approval purposes (and received different royalty treatment and equity participation). The total production as of September 2019 from the original and expansion fields has been 297 million barrels of oil. ${ }^{8}$ The project's operator, Husky Energy, is in the process of constructing a $241 \mathrm{~m}$ high concrete gravity supported wellhead platform, for use in the next expansion, the West White Rose Project, which is expected to go to first oil in $2022 .{ }^{9}$

\section{HEBRon}

The Hebron development was first discovered in 1980. It is located $350 \mathrm{~km}$ east of St. John's in the Jeanne d'Arc Basin, approximately $10 \mathrm{~km}$ south of the Terra Nova Project. It commenced production in $2017,{ }^{10}$ through a gravity-based structure built in Newfoundland and Labrador. ExxonMobil Canada is the operator of the Hebron field. Production has been increasing gradually, with 51 million barrels of oil produced to September 2019. ${ }^{11}$

Hibernia Management and Development Corporation, “Hibernia Southern Extension,” online: $<$ hibernia. ca/hse.html>.

5 Suncor Energy, "Terra Nova" (2019), online: < suncor.com/about-us/exploration-and-production/eastcoast-canada/terra-nova>.

Cumulative Production, supra note 3.

Suncor Energy, supra note 5.

Cumulative Production, supra note 3.

Husky Energy, "Quick Facts West White Rose Project," online: <wwrp.huskyenergy.com/servlet/ servlet.FileDownload? file=00P1L00000r6Sj1UAE $>$.

10

Chevron Canada Limited, "Hebron Project Achieves First Oil" (March 2018), online: <chevron.com/ stories/hebron-project-achieves-first-oil>.

Cumulative Production, supra note 3. 


\section{A Shared History: Projects of an Era}

The Hibernia, Terra Nova, White Rose, and Hebron Projects (the Projects) have had differences in both the timing and the avenues they have taken from first discovery to eventual development and production. Even these differences, however, can be seen as having been variations on a series of common physical and legal themes. These similarities between the Projects far exceed their differences.

\section{A. Similarity 1: The Supporting Legal Structure}

All of the Projects exist under the underlying land interest regulatory regime established under the Canada Newfoundland and Labrador Atlantic Accord Implementation Act and the Canada-Newfoundland and Labrador Atlantic Accord Implementation (Newfoundland) Act. ${ }^{12}$ This regime has existed essentially unchanged since the legislation was introduced in 1987. It includes the granting of exploration licences, the progression of an exploration licence to a significant discovery licence upon certain reservoir standards being proven, and a production licence upon a commercial discovery being established. Each of the Projects operates on one or more production licences issued through this process.

Parallel with this licencing process is the requirement to file and obtain approval from the CNLOPB of a benefits plan and a development plan. ${ }^{13}$ The benefits plan is required to demonstrate the proponent's plans to satisfy the statutory benefits requirements under the Accord Act, including providing first opportunity for employment to qualified residents of Newfoundland and Labrador, and providing first opportunity to competitive suppliers in Newfoundland and Labrador. The development plan requires the proponent to describe and demonstrate the full scope of the planned project, including the mode and timing of development, the reservoir recovery plan, the system of production, as well as detailed technical information respecting the project. $^{14}$

For a project, approval of the benefits plan is at the discretion of the CNLOPB; however, approval of the development plan, if approved by the CNLOPB, is subject to having that approval confirmed by the federal and provincial governments as a "fundamental decision." 15 The requirement for this ultimate governmental approval is the leverage the Government of Newfoundland and Labrador uses to obtain commitments directly respecting benefits, royalties, and since 2007 , equity interests as part of a commercial negotiation with its proponents.

\section{B. Similarity 2: THE History OF DEVELOPMENT}

As set out above, the Projects are a result of exploratory drilling activities that happened in the late 1970 s to early 1980 s. Petroleum exploration activity was occurring in the NL

12 SC 1987, c 3; SN 1986, c 37. The two acts are mirror pieces of legislation and are jointly referred to as the Accord Act. All pinpoints to section numbers of the Accord Act in this article refer to sections of the federal legislation.

Ibid, ss 45, 139.

Ibid, s 139.

Ibid, ss 31-40. 
Offshore in the 1960s and 1970s, but with limited success and waning enthusiasm as a result of up to 40 dry wells. ${ }^{16}$ However, the price spikes resulting from the 1973 energy crisis spurred further development and the Hibernia find in 1979 confirmed that commercial petroleum reserves did exist in the NL Offshore. ${ }^{17}$ This spurred the subsequent drilling that led to the original discoveries of all of the Projects between 1979 and 1984. In this way, the Projects can be said to share a common bond of being the legacy of an energy crisis that occurred almost 50 years ago.

\section{Similarity 3: The Proponents}

The ownership interests of the Projects have been defined by a small group of repeating players. ExxonMobil Canada holds 33 percent, 19 percent, and 36 percent interests (all figures rounded) in Hibernia, Terra Nova, and Hebron respectively and operates the Hibernia and Hebron Projects. Suncor holds shares in all four projects, with 20 percent, 38 percent, 26 percent, and 21 percent interests respectively in Hibernia, Terra Nova, White Rose, and Hebron, and operates the Terra Nova Project. Chevron Canada is close behind at 27 percent of Hibernia, 1 percent of Terra Nova, and 30 percent of Hebron. Husky Energy holds 13 percent interests in Terra Nova and 69 percent in the White Rose project, which it operates. Finally, Equinor Canada Ltd. holds 5 percent of Hibernia, 15 percent of Terra Nova, and 9 percent of Hebron. Put another way, these five companies combined hold at least 85 percent interests in each of the Projects. ${ }^{18}$

This concentration of interests has its origins in part in the original exploration activities in the NL Offshore predating the Atlantic Accord and the companies who were engaged in those exploration activities. Mobil Oil and Chevron drilled many of the original wells in the jurisdiction in the 1970s, including the original wells which led to the discovery of the reservoirs that would become the Hibernia and Hebron Projects. Suncor's predecessor, PetroCanada, and Husky Energy drilled the wells discovering the Terra Nova and White Rose Projects in 1984. The legislative regime for licences contributed significantly to the longterm involvement of these companies. Once the exploratory drilling identified petroleum reservoirs, the parties were issued significant discovery licences for the area. Under the Accord Act, significant discovery licences are perpetual once issued. ${ }^{19}$ They have neither an expiration date nor any carrying charge to maintain. As a result, once the companies obtained the significant discovery licences from their original drilling activities, they could hold the

16 DM Burden, J Dobbin \& MG Sheppard, "Petroleum Exploration and Resource Potential of Offshore Newfoundland and Labrador" (Paper delivered at Annual AAPG/SEPM/EMD/DPA Convention, Dallas, Texas, 17 April 1983), online: <osti.gov/biblio/6183880-petroleum-exploration-resource-potentialoffshore-newfoundland-labrador $>$.

17 Leah Fusco, "Offshore Oil: An Overview of Development in Newfoundland and Labrador" in Oil, Power and Dependency: Global and Local Realities of the Offshore Oil Industry in Newfoundland and Labrador (Memorial University of Newfoundland, 2007) at 2, online: <ucs.mun.ca/ oilpower/ documents/NL\%20oil\%207-25-1.pdf>.

18 The percentages referenced regarding Hibernia, Terra Nova, and Hebron were compiled from information at the official Project websites at: <www.hibernia.ca $>;<$ www.suncor.com/en-CA/about-us/ exploration-and-production/east-coast-canada/terra-nova $>$; and <www.hebronproject.com/project/ cov.aspx $>$, respectively. The White Rose Project information was obtained from Suncor, "Joint Ventures," online:<www.suncor.com/en-CA/about-us/exploration-and-production/east-coast-canada/ joint-ventures>. 
discovered interest in inventory until it was in a position to develop, without pressure to develop as a result of impending licence expiry.

Since 2007, this group of five major players has been joined by Nalcor Oil \& Gas Corporation, the 100 percent owned crown corporation of the Government of Newfoundland and Labrador (the Province). In the Energy Plan 2007, the Province announced it would be seeking equity interests in future development projects. ${ }^{20}$ It has since acquired interests in the Hebron Project (4.9 percent), White Rose Growth Project (5.0 percent), and Hibernia Southern Extension Project (10 percent). ${ }^{21}$ As noted above, these interests have been acquired through the Province's negotiating position on the development plan approval process for each Project.

\section{SimILARITY 4: LOCATION}

Also as noted above, all four Projects are located on the Grand Banks east of the island of Newfoundland, in a geologic formation known as the Jeanne d'Arc Basin, between 300 $\mathrm{km}$ and $350 \mathrm{~km}$ offshore. In fact, all four Projects operate almost within sight of each other. The Projects form an inverted triangle with Hibernia to the northwest, $300 \mathrm{~km}$ from St. John's; White Rose approximately $50 \mathrm{~km}$ east; and Hebron and Terra Nova as the southern point about $30 \mathrm{~km}$ below the two and $10 \mathrm{~km}$ apart.

This geographic concentration has a number of logistical advantages. Most of the Projects share onshore supply bases and facilities, helicopter facilities and other services, provided by third-party vendors in St. John's. Transportation tanker service systems have been shared between various Projects. Supply vessels are able to provide support in emergencies. This geographic proximity creates other similarities between the Projects. Because they are all on the Grand Banks, they occur in relatively shallow water $-80 \mathrm{~m}$ to $130 \mathrm{~m}$. For scale, the Terra Nova FPSO is $292 \mathrm{~m}$ long, or about twice the water depth in which it operates. This similarity in depth permits similar development and operational technologies to be developed and deployed by the Projects, such as remote operated vehicles and subsea technologies.

\section{E. Similarity 5: ENVIRonMENTAL ASSESSMENT}

The environmental assessment processes to which the original Projects were subject were not entirely similar, but showed a convergence in the treatment for the later projects.

It is not a mischaracterization to state that the Hibernia Project went through environmental review before there was an environmental assessment regime to apply. The Hibernia Project Environmental Review Panel (the Panel) was established on 15 March 1985 by the Governments of Canada and Newfoundland and Labrador. These governments had 2007), online: <assembly.nl.ca/business/electronicdocuments/FocusingOurEnergy-EnergyPlan2007. pdf $>$.

21 Nalcor Energy, “Development and Production," online: $<$ nalcorenergy.com/nalcor-operations/oil-andgas/development-and-production/>. 
only signed the Atlantic Accord a month before, ${ }^{22}$ the implementation legislation which formally created the CNLOPB was at least a year away. ${ }^{23}$ At this point in 1985, there was also no environmental protection legislation in either the federal jurisdiction or the Province's jurisdiction. Instead, the process implemented by the Panel was further to federal guidelines for environmental assessments issued in July 1980 and the Province's guidelines issued in January $1981 .^{24}$

Mobil Oil as Project proponent filed its environmental impact statement with the Panel on 15 May 1985. The Panel held public hearings on the environmental impact statement, and issued a report in December 1985 (seven months after the environmental impact statement was submitted). The Panel made 50 recommendations to the two levels of government as to the operational requirements of the Project. ${ }^{25}$ The Panel's report was referenced in and guided the decision of the CNLOPB in June 1986, in its approval of the development plan for the Hibernia Project. In particular, the CNLOPB stated that the Panel's recommendations on "employment, technology transfer and supply of goods and services form the basis for much of the Board's Benefits Plan Decision."26

It was almost ten years later before the next offshore development, the Terra Nova Project, underwent environmental assessment. By 1996, both Canada and the Province had environmental protection legislation in place. ${ }^{27}$ The Terra Nova Project environmental assessment was conducted in conjunction with the CNLOPB and the two governments through a three-party memorandum that had the environmental assessment process conducted by a panel appointed by the parties but managed by the CNLOPB as a responsible authority under the federal legislation. This panel conducted its hearing concurrently with the development plan review process. ${ }^{28}$ The purpose of the arrangement was to have "a single joint public review process which satisfies the legislative requirements of all parties. ${ }^{29}$ The development plan application and the environmental impact statement were submitted to the CNLOPB on the same date in August 1996; the CNLOPB referred the environmental impact statement to the panel appointed pursuant to a memorandum of understanding in December 1996. This panel reported to the CNLOPB and the governments in August $1997 .{ }^{30}$ It made

The Atlantic Accord: Memorandum Of Agreement Between The Government Of Canada And The Government Of Newfoundland And Labrador On Offshore Oil And Gas Resource Management And Revenue Sharing, 11 February 1985, online: <cnlopb.ca/wp-content/uploads/guidelines/aa_mou.pdf> [Atlantic Accord].

23 Accord Act, supra note 12.

24 Canadian Environmental Assessment Agency and Hibernia Environmental Assessment Panel, Hibernia Development Project: Report of the Hibernia Environmental Assessment Panel, (Ottawa: Minister of Supply and Services Canada, 1985) at 9, online: <publications.gc.ca/collections/collection_2017/aceeceaa/En105-34-1986-eng.pdf $>$ [Hibernia EA].

$25 \quad$ Ibid at $46-47$

26 CNLOPB, Decision 86.01 re: Application for Approval of Hibernia Canada-Newfoundland Benefits Plan and Hibernia Development Plan (St John's, NL: CNLOPB, June 1986) at 5, online: <cnlopb.ca/ wp-content/uploads/news/d86_01e.pdf $>$ [Decision 86.01]. Canadian Environmental Assessment Act, SC 1992, c 37 [CEAA 1992]; Environmental Assessment Act, RSN 1990, c E-14.

28 CNLOPB, Memorandum of Understanding Concerning Environmental Assessment of the Terra Nova Development, 17 June 1996 at 5-6, online: <cnlopb.ca/wp-content/uploads/tneamouf.pdf>.

29 CNLOPB, News Release, "C-NLOPB Approves Terra Nova Canada-Newfoundland Benefits Plan and Development Plan,” (15 January 1998), online: <cnlopb.ca/news/nr19980115eng_background/>. Ibid. 
75 recommendations $;^{31}$ many were subsequently incorporated into the development plan approval decision by the CNLOPB.

The original White Rose Project environmental assessment process followed relatively quickly after that for Terra Nova in 2001 , but the process again was somewhat different. There was again a joint review; however this time, the review was directly tied into the CNLOPB's development plan application process. Husky submitted a comprehensive study report under the CEAA $1992^{32}$ provisions in January $2001 .^{33}$ The CNLOPB as the responsible authority accepted the comprehensive study report from Husky; after review it was sent to the federal environment Minister for review. The Minister approved the comprehensive study report and sent it back to the CNLOPB to proceed, determining that a review panel was not required as the Project is "not likely to cause significant adverse environmental effects." 34 The CNLOPB then conducted the environmental review as part of the work by the Commissioner appointed by the CNLOPB to hold public hearings into both the environmental issues as well as the development plan application. This approach was touted by the Commissioner as the first "stand-alone public review" for an offshore project. ${ }^{35}$ No separate review panel was appointed.

It was another ten years before the Hebron Project would undergo its environmental assessment process; despite the passage of time the result was strikingly similar. Hebron, as with White Rose, was required to submit a comprehensive study report under the Canadian Environmental Assesssment Act, ${ }^{36}$ and the report was submitted to the federal Minister of the Environment in September 2011. In December 2011, the Minister determined that the project was "not likely to cause significant adverse environmental effects" ${ }^{37}$ and referred the environmental assessment process back to the CNLOPB as the responsible authority. Again, no separate review panel was appointed. The commissioner appointed by the CNLOPB to conduct the review of the development plan proceeded to review environmental issues as set out under the CNLOPB's development plan processes. The report of the Hebron Project's public review commissioner (dated February 2012) was incorporated into the eventual CNLOPB approval for the Hebron Project. ${ }^{38}$

31 Canadian Environmental Assessment Agency, Terra Nova Development: Report of the Terra Nova Development Project Environmental Assessment Panel, (Ottawa: CEAA, 1997) at 8, online: <ceaaacee.gc.ca/default.asp?lang=En\&n=804525A3-1\&offset $=8 \&$ toc $=$ show $>$.

Supra note 27.

33 HM Clarke, Report of the Public Review Commissioner for the White Rose Development Application (CNLOPB, 2001) at 2-3, online: <cnlopb.ca/wp-content/uploads/news/d01_01comm_rpt.pdf $>$ [White Rose Report].

34 CNLOPB, Decision 2001.01 re: Application for Approval of White Rose Canada-Newfoundland Benefits Plan and White Rose Development Plan (St John's, NL: CNLOPB, 2001) at 177-78, online: $<$ cnlopb.ca/wp-content/uploads/news/d01 01.pdf $>$.

White Rose Report, supra note 33 at i.

SC 2012, c 19, s 52 [CEAA 2012].

CNLOPB, Report of the Hebron Public Review Commissioner for the Hebron Development Application, (2012) at 81, online <cnlopb.ca/wp-content/uploads/hebpubrev.pdf>.

CNLOPB, Decision Report 2012.01 re: Hebron Development Application (CNLOPB, 2012), online: $<$ cnlopb.ca/wp-content/uploads/news/hebdecision042012.pdf $>$ [Decision 2012.01]. It should be noted that this decision report differs from those of the CNLOPB for previous projects in its brevity, being six pages long in total. The issues relating to environmental protection were deferred on the requirement for the proponent to file an Environmental Protection Plan as required by CNLOPB Regulations. 


\section{F. Similarity 6: THE Royalty REgIME}

The authority to determine the fiscal royalty regimes applicable to petroleum development projects in the NL Offshore lies with the Province. It comes by this authority through a circuitous route. After the Supreme Court of Canada determined the offshore to be federal jurisdiction, ${ }^{39}$ a political compromise was reached in 1985 in the Atlantic Accord. ${ }^{40}$ The Atlantic Accord was an agreement between the Governments of Canada and of Newfoundland and Labrador which established a joint management regime in the offshore, including the establishment of the CNLOPB. At article 36, it also committed that the Province would have the authority to set royalties in the offshore as if the resources were created on land:

The federal legislation implementing the Accord, therefore, will permit the Government of Newfoundland and Labrador to establish and collect resource revenues and provincial taxes of general application as if these petroleum-related activities were on land within the province, through incorporation by reference of Newfoundland laws (as amended from time to time), or through other appropriate legislative mechanisms. ${ }^{41}$

The Accord Act, referred to above, were the legislative mechanisms introduced in the years after 1985 to implement the commitments set out in the Atlantic Accord. The bargain on royalties was effected through section 97 of the Accord Act, which used the legislative tool of incorporation by reference to adopt the legislation and regulations passed by the Province under its Petroleum and Natural Gas Act ${ }^{42}$ for application to the offshore:

(1) In this Division, Petroleum and Natural Gas Act means Part II of the Petroleum and Natural Gas Act, R.S.N.L. 1990, c. P-10, as amended from time to time.

(2) There is hereby reserved to Her Majesty in right of Canada and each holder of a share in a production licence is liable for and shall pay to Her Majesty in right of Canada, in accordance with subsection (4), the royalties, interest and penalties that would be payable in respect of petroleum under the Petroleum and Natural Gas Act if the petroleum were produced from areas within the Province.

(3) Notwithstanding subsection (2), where petroleum is subject to a royalty under the Petroleum and Natural Gas Act, that petroleum is not subject to a royalty under subsection (2).

(4) Subject to this Act and the regulations, the Petroleum and Natural Gas Act and the regulations referred to in subsection (4.1) apply, with any modifications that the circumstances require, for the purposes of this section and, without limiting the generality of the foregoing,

(a)

a reference in that Act to Her Majesty in Right of the province is to be read as a reference to Her Majesty in right of Canada; and

Reference re Newfoundland Continental Shelf, [1984] 1 SCR 86 at 127.

Royal Commission on Renewing and Strengthening Our Place In Canada, Overview Paper on the 1985 Canada-Newfoundland Atlantic Accord, by John C Crosbie (2003) at 259-68, online: <gov.nl.ca/ publicat/royalcomm/research/Crosbie.pdf $>$.

Atlantic Accord, supra note 22, art 36.

Petroleum and Natural Gas Act, RSNL 1990, c P-10 [PNG Act]. 
(b) a reference in that Act to the province is to be read as a reference to the offshore area.

The following regulations apply for the purposes of subsection (4):

(a) any regulations made under the Petroleum and Natural Gas Act; and

(b) any regulations made under an Act that was replaced by the Petroleum and Natural Gas Act, to the extent that those regulations remain in force in accordance with the laws of the Province and are not inconsistent with the Petroleum and Natural Gas Act. ${ }^{43}$

Part II of the PNG Act of the Province establishes the regime for royalties onshore in the Province, the details of which are set out in regulation. The PNG Act also contains section 33 , which provides that the royalty regulations can be overridden through a contract between the Province and the holder of a petroleum interest:

The Lieutenant-Governor in Council may make an agreement with an interest holder, with one or more holders of shares in a lease or with another person, including an agreement that is inconsistent with regulations made under this Part.

(2) Where an agreement made under subsection (1) is inconsistent with regulations made under this Part the agreement shall prevail. ${ }^{44}$

Through these legislative mechanisms, regulations passed by the Province to establish royalty regimes onshore are adopted and applied offshore; however, such regimes are subject to being varied by a negotiated agreement between the Province and a development project's interest owners.

Application of this convoluted legal structure has done nothing to reduce the complexity of the situation. Each of the Projects has dealt with royalties in a somewhat different manner, through a series of negotiations that, if one starts with the 1990 Hibernia Agreement, extended over 18 years to the Hebron Project in $2008 .{ }^{45}$ The Hibernia Royalty Agreement, executed in 1990, was expressly stated to be a wholly commercial royalty agreement between the Province and the Hibernia Project owners, without reliance upon the authority to impose royalties by regulation under the Accord Act or the PNG Act. The only regulatory royalty regime implemented was a nominal royalty under the PNG Act of one cent per barrel, designed solely to exert the authority granted under the relatively new and untested Accord Act legislation. ${ }^{46}$

At the start, the intention was that the Terra Nova Project royalty regime would also be negotiated between the proponents and the Province, but as a result of the inability of the parties to reach agreement, it eventually became a regulated royalty. The Province passed the

There are effectively six regimes offshore, as the Hibernia Southern Extension project and the White Rose Extension project received different royalty treatment than their associated main projects. Oil Royalty Regulations, CNLR 22/96. 
Royalty Regulations, $2003,{ }^{47}$ as the first complete exercise of the royalty authority granted under the Accord Act. It set out a "generic" royalty regime, which applied to all postHibernia developments. However, for the Terra Nova Project it contained project-specific variations that had been incorporated to reflect aspects of the Terra Nova royalty regime which had been agreed between the parties. The original White Rose Project was subject to this "generic" regulatory royalty without an overlaying agreement. The Hebron Project represented the fullest implementation for the concept of section 33, having a negotiated contractual arrangement which relied upon the Royalty Regulations, 2003 as their foundation, but varied, and in some places froze, the implementation of these regulations for the purposes of the project. ${ }^{48}$

Despite this disparate assemblage of legal structures for the royalty regimes, their commercial and fiscal terms were relatively consistent. Each regime was a variation on the framework established by the original Hibernia Royalty Agreement. ${ }^{49}$ Each consists of:

- a basic royalty rate of between 1 percent and 10 percent applicable to gross production less transportation costs, with rate increases either in response to the passage of time or cumulative production, ${ }^{50}$

- the concept of "payout" calculated as the total aggregate revenues compared to total aggregate capital and operating costs, plus a return allowance factor, as creating the threshold triggers for incremental royalties; ${ }^{51}$

- the recognition of pre-development costs as inclusions towards payout calculations, using similar eligibility rules as applied to capital and operating costs; ${ }^{52}$

- incremental royalties imposed as fixed percentages applicable in stages or "tiers" between 10 percent and 30 percent (with maximum cumulative rates of 42.5 percent), calculated upon a net revenue for each interest owner; ${ }^{53}$

- transition between royalty tiers being a result of payout calculations using progressively higher return allowance factors $;{ }^{54}$ and

\section{NLR 71/03.}

The history of the negotiation of the royalty regimes for the four current offshore projects has been set out in detail elsewhere and it is not the intention to review those issues here; for a full review see, RJ (Jack) Thrasher \& Simon Baines, "Developments in Newfoundland and Labrador Offshore Royalties: From Hibernia to Hebron and Back" (2014) 37:1 Dal LJ 33.

Ibid at 44-50.

Government of Newfoundland and Labrador, Hibernia Project Royalty Regime, online: <nr.gov.nl.ca/ $\mathrm{nr} /$ energy/petroleum/offshore/hibernia.pdf $>$ [Hibernia Regime]; Royalty Regulations, 2003, supra note 47, ss 73, 90; Hebron Fiscal Agreement, 20 August 2008 at 36-37, online: <nr.gov.nl.ca/nr/energy/ petroleum/offshore/projects/hebron_fiscal_aggre.pdf $>$.

Royalty Regulations, 2003, ibid, s $1 \overline{0}$.

Ibid, s 64.

Ibid, ss 74, 91. Hibernia Regime, supra note 50.

Royalty Regulations, 2003, ibid, ss 10-11; Hibernia Regime, ibid. 
- dispute resolution systems using an international arbitration model; the contractual commercial settlement model originally incorporated into the Hibernia Royalty Agreement has been adopted in the Royalty Regulations, 2003. ${ }^{55}$

The royalty regimes applicable to each of the Projects can therefore be seen to be variations on a similar structural theme developed and relied upon by the Province and by proponents for over 20 years.

\section{A DifFERENT AND UnCERTAIN Future}

While the Hebron Project only started production in late 2017, it is older in terms of the legal and regulatory context of its development. The fiscal and benefits terms with the Province were finalized in $2008,{ }^{56}$ its development project approval by the CNLOPB occurred in $2012,{ }^{57}$ and it was sanctioned in early $2013 .{ }^{58}$ In the intervening six years, the offshore industry has changed significantly. This can be seen in a review of the same parameters as above, looking forward to future development projects and the legal context in which they will move forward.

The differences facing future developments are exemplified by the only announced potential development project: the Bay Du Nord project proposed by Equinor Canada Ltd. It is a proposed deep water development in the Flemish Pass area of the offshore, based upon wells drilled since 2009, and significant discovery licences issued in 2013 and 2017. ${ }^{59}$ The proposed development would occur approximately $450 \mathrm{~km}$ east-northeast from St. John's in an area with a water depth of $1100 \mathrm{~m} .{ }^{60}$ This depth necessitates development through a floating production system - Equinor has proposed a FPSO. ${ }^{61}$ The closest existing production facility would be the White Rose SeaRose FPSO, approximately $240 \mathrm{~km}$ southwest of the proposed development. ${ }^{62}$ As of November 2019, this project has not been sanctioned. Equinor has filed a project description to start the environmental assessment process, and in July 2018 it was announced it has agreements with the Province on both royalties and benefits issues. ${ }^{63}$ If sanctioned, Equinor has anticipated first oil in $2025 .^{64}$

Whether the Bay Du Nord Project ultimately proceeds, it represents a useful example of the characteristics that are expected to be seen in the future development projects in the NL Offshore.

Royalty Regulations, 2003, ibid, s 48.

Government of Newfoundland and Labrador, News Release, "Hebron Agreement Signals New Era in Province's History" (20 August 2008), online: <releases.gov.nl.ca/releases/2008/exec/0820n04.htm>. Decision 2012.01, supra note 38 at 2 .

Hebron, News Release, "Hebron Co-Ventures Reach Sanction," (4 January 2013), online: <hebron project.com/mediacentre/2013/sanction.aspx>.

CNLOPB, "Current Significant Discovery Licenses Issued" (24 July 2019), online: <cnlopb.ca/wpcontent/uploads/sdlgbr.pdf>.

Equinor Canada Ltd, "Bay Du Nord Development Project: Project Description Summary" (Equinor, 2018) at 8, online: <iaac-aeic.gc.ca/050/documents/p80154/123011E.pdf> ["Bay Du Nord Project Description"].

Ibid at 9 .

Ibid.

Government of Newfoundland and Labrador, News Release, "Premier Ball Marks First Step into New Frontier for Oil and Gas Industry,” (26 July 2018), online: <releases.gov.nl.ca/releases/2018/exec/ 0726n01.aspx> ["New Frontier"].

"Bay Du Nord Project Description," supra note 60 at 23. 


\section{A. Difference 1: The Supporting Legal Structure}

There is no indication of any changes in the fundamentals of the land licencing regime currently operated by the CNLOPB for any future projects. This stability is expected both in respect of the details of the licencing regime itself, and in respect of the CNLOPB, the administrative entity administering the regime. This is not surprising given the primacy of the CNLOPB in the Atlantic Accord's joint management commitments. This stability in the NL Offshore is not the case elsewhere in Canada, where Bill C-69 ${ }^{65}$ (discussed below) includes the restructuring and replacement of the National Energy Board, an analogous federal regulator to the CNLOPB.

Significant changes are, however, occurring around this system. One is the identification by Canada of areas of the NL Offshore as marine protected areas and marine refuges. Canada has made international commitments to protect ecologically important and biodiverse regions of its offshore by having up to 10 percent of the area subject to conservation actions by $2020 .^{66}$ It has been pursuing this objective by designating various locations in the oceans surrounding the country as protected areas. While the terms marine protected areas and marine refuges can be used interchangeably by media, there is a significant difference between the two levels of designation. Marine protected areas are created pursuant to a designation under the Oceans Act. ${ }^{67}$ That legislation provides that the declaration of a marine protected area can specify the prohibited activities in the area, but once so prescribed the area is statutorily protected on the threat of regulatory prosecution. ${ }^{68}$ Canada has made the analogy that these areas will be protected from development activities in a manner similar to a national park. ${ }^{69}$

Marine refuges, in contrast, are not set out in any legislation and are areas identified and created purely as a matter of policy by the Government of Canada. Canada has also identified these areas as being ecologically sensitive, but it is protecting the areas through various policy means as opposed to a marine protected area designation.

In the NL Offshore, the Department of Fisheries and Oceans (the Department) in December 2017 proclaimed the Northeastern Slope Marine Refuge off northeastern Newfoundland as an area including important coral and sponge formations. This refuge has an area of over $53,000 \mathrm{~km}^{2}$, encompassing a significant portion of the Orphan Basin. ${ }^{70}$ The

Bill C-69, An Act to enact the Impact Assessment Act and the Canadian Energy Regulator Act, to amend the Navigation Protection Act and to make consequential amendments to other Acts, 1st Sess, 42nd Parl, 2019 (assented to 21 June 2019), SC 2019, c 28 [Bill C-69].

66 These commitments follow up on Canada's commitments under the United Nations Convention on Biological Diversity, 4 June 1993, 1760 UNTS 79 (entered into force 29 December 1993); a summary description can be found under Canada, Department of Fisheries and Oceans, Operational Guidance for Identifying 'Other Effective Area-Based Conservation Measures' in Canada's Marine Environment (2017), online: <dfo-mpo.gc.ca/oceans/publications/oeabcm-amcepz/index-eng.html .

$67 \quad \mathrm{SC} 1996, \mathrm{c} 31, \mathrm{~s} 35$

$68 \quad$ Ibid, ss $35,39.6$.

69 Fisheries and Oceans Canada, News Release, "Canada Announces New Standards for Protecting Our Oceans," (25 April 2019) online: <canada.ca/en/fisheries-oceans/news/2019/04/canada-announces-new standards-for-protecting-our-oceans.html $>$ ["Protecting Our Oceans"].

70 Fisheries and Oceans Canada, "Northeast Newfoundland Slope Closure" (2019), online: < dfo-mpo. gc.ca/oceans/oeabcm-amcepz/refuges/northeastnewfoundlandslope-talusnordestdeterreneuve-eng.html $>$. 
Department declared and enforced this refuge through the banning of all fishing activity that could have contact with the ocean bottom.

Until recently, the interaction of these federal actions under the Oceans Act and the Fisheries $A c t^{71}$ with petroleum regulation has been somewhat unclear. The unilateral federal declarations did not automatically apply to petroleum regulation, in part because of the joint management regime under the Accord Act, which created the shared jurisdiction over these activities in the CNLOPB. As a result, the CNLOPB continued to issue exploration licences for the Orphan Basin area, including in the Northeastern Slope Marine Refuge. The refuge declaration did not apply to or preclude petroleum exploration activities; instead, the physical description of the refuge area excluded the area of exploration licences issued to that time. This has been controversial in the fishing and environmental communities, who were banned from the refuge area but witness petroleum activity continuing unimpeded. ${ }^{72}$

On 1 April 2019, the Governments of Canada and Newfoundland and Labrador announced the negotiation of a new Atlantic Accord Agreement (the Agreement) on offshore petroleum matters. ${ }^{73}$ While described as a revision to the original Atlantic Accord, this new Agreement is primarily concerned with a new revenue agreement relating to Canada's dividends as partowner of the Hibernia project. However, it also contains the first acknowledgement of a reconciliation of the marine protection and petroleum exploration regimes. The Agreement expressly acknowledged that exploration could continue in the Orphan Basin, but that it would not occur in the area of the then-proposed Laurentian Channel Marine Protected Area. ${ }^{74}$ This represented the first integration between the two regimes, and will presumably be enforced either through legislative amendments of the Accord Act or a joint directive to the CNLOPB. Given Canada's international commitments for the protection of 10 percent of the coastal area, future additional declarations could have significant impacts on petroleum activities in the NL Offshore.

There is also the prospect that the CNLOPB's other functions may change in the future. The CNLOPB is the primary safety regulator in the NL Offshore under the Accord Act. After the crash in 2009 of a helicopter ferrying workers offshore which resulted in the death of 17 passengers, a Public Inquiry into Offshore Helicopter Safety recommended the establishment of an independent safety regulatory for the NL Offshore, separate from the CNLOPB. ${ }^{75}$ There has been no indication of an intention of either level of government to act on this recommendation, but it has been recently recognized it may occur in response to a significant expansion of activity in the offshore. ${ }^{76}$

$71 \quad$ RSC 1985, c F-14.

Fish, Food and Allied Workers, "New Marine Refuges Expel Fish Harvesters While Permitting Seismic" (21 December 2017), online: < ffaw.nf.ca/en/the-latest/news/new-marine-refuges-expel-fish-harvesterspermitting-seismic/>.

73 Government of Newfoundland and Labrador, News Release, "Landmark Atlantic Accord Agreement Achieved" (1 April 2019), online: <releases.gov.nl.ca/releases/2019/exec/0401n07.aspx>.

"Protecting Our Oceans," supra note 69; this MPA was formally announced on 29 April 2019, with a ban on petroleum activity in the $11,580 \mathrm{~km}^{2}$ area.

The Honourable Robert Wells, Commission of Inquiry into Offshore Helicopter Safety Inquiry: Report and Recommendations, vol 1 (St John's, NL: CNLOPB, 2010) at 302, online: <cnlopb.ca/wp-content/ uploads/ohsi/ohsir_voll.pdf>.

76 "Offshore Safe Enough in C-NLOPB's Hands for Now: Natural Resources Minister," CBC News (13 March 2019), online: <cbc.ca/news/canada/newfoundland-labrador/offshore-safety-hoa-1.5053353>. 


\section{B. DifFERENCE 2: THE HiSTORY OF DEVELOPMENT}

The existing Projects are the product of drilling activity that occurred in the late 1970s and early 1980s. The lead times to bring these discoveries to market were measured in decades. While there are still a number of significant discovery licences from this period, the anticipation is that the next development projects will grow from recent and planned exploration activities, and that the lead time between discovery and development will be significantly shortened. The best example of this is the proposed Bay du Nord Project, which is based on a series of discoveries since 2009. The significant increase in exploration licence activity in the past five years, and planned drilling activity, increases the likelihood of similar significant discoveries in the future.

\section{Difference 3: The Proponents}

The increase in exploration licence activity has resulted in a number of new entrants into the NL Offshore. While the five major local players of ExxonMobil, Chevron, Suncor, Husky Energy, and Equinor are still involved, the new exploration licencing activities are being driven by new entrants into the NL Offshore. The Government of Newfoundland and Labrador, in its 2017 "Advance 2030" document, identified "7 new entrants in the past 2 years"; ${ }^{77}$ this was before the announcement in late 2018 that BHP Petroleum had acquired its first interests in the offshore, bringing the total new entrants to eight. ${ }^{78}$ There is obviously a long road between obtaining the exploration licence rights and being a participant in a development project. However, the historically limited table of potential development players in the NL Offshore has expanded.

There are a number of implications for this as the industry expands and develops. For industry, it highlights that the NL Offshore is increasing in international visibility, with major international companies reviewing its prospectivity and attractiveness for operations. It will likely require a more comprehensive administrative process on the part of the Province and the CNLOPB, having to deal with an increased number of different proponents, some with widely varied corporate cultures and experiences, and some without any corporate memory of the lessons learned in the past 20 years of operations and the experience that the five major local companies possess. Their processes will have to adjust to accommodate complete strangers to the NL Offshore; as discussed below, this may have been the impetus behind some of the changes to the Province's royalty regime.

\section{DIFFERENCE 4: LOCATION}

Unlike the relatively close proximity to each other of the Projects in the Jeanne d'Arc Basin, the location of potential new development projects will likely be more varied. The new exploration licences being issued are in new areas outside the traditional Jeanne d'Arc Basin. Recent exploration licences, particularly since 2013, have focused on the Flemish Pass nr/advance30/pdf/Oil_Gas_Sector_FINAL_online.pdf>.

78 CNLOPB, "Current Exploration License" (28̄ June 2019), online: <cnlopb.ca/wp-content/uploads/elgbr. pdf> [Exploration License]. 
and Orphan Basin. The Flemish Pass area, the location of the proposed Bay du Nord project, is on the eastern most edge of the Grand Banks, and includes deep water between the slope of the Grand Banks and the Flemish Cap, an underwater plateau located over $500 \mathrm{~km}$ from St. John's. Water depths in the areas for which exploration licences have been issued go up to $1100 \mathrm{~m}^{79}$ The other area for exploration licence activity has been the Orphan Basin, a large sedimentary basin north of and contiguous to the Grand Banks. Depths in the Basin in the areas exploration licences have been granted can range to $2000 \mathrm{~m} .{ }^{80}$ Orphan Basin exploration locations are closer to the island of Newfoundland than the Flemish Pass locations, but equally as far from the established supporting onshore infrastructure of the northeast Avalon Peninsula as the Flemish Pass prospects.

These factors increase the cost and complexity of any eventual developments, including in terms of the processes and procedures of safely drilling in deep water environments, as well as the logistics of supporting such activities so far offshore.

\section{E. Difference 5: EnVIronmental ASSESSMENT}

A review of the changes to the environmental assessment regime that have occurred since the Projects were approved (which for Hebron's approval would be 2010) requires a review of the known and the unknown, and the potential implications of each.

The "known" would be CEAA 2012, and the significant changes it will bring to development project reviews (including upon the process that the Bay du Nord Project will undergo). The "unknown" is Bill C- $69,{ }^{81}$ and the additional implications it may have for development projects in whatever form it eventually may take if passed.

\section{CEAA 2012}

The Terra Nova, White Rose, and Hebron projects were developed under the CEAA 1992. The CEAA 2012 marked a complete revision to this environmental assessment system. There is no longer a screening process conducted by a responsible authority, nor the prospect of a comprehensive study report (these were eliminated). Instead, an environmental assessment process is required, commencing with the filing of a project description and an environmental impact statement. ${ }^{82}$ In the event the Minister determines that it is in the public interest, having regard to whether the project may cause significant adverse environmental effects or the level of public concern related to potential adverse environmental effects, the Minister may refer the matter to review by a panel. ${ }^{83}$

For the NL Offshore, a more fundamental change was that the CEAA 2012 relieved the CNLOPB of its duties as responsible authority in the context of offshore petroleum developments. Instead, section 15 of the CEAA 2012 specified that the Canadian

\footnotetext{
79 CNLOPB, "Eastern Newfoundland Region: Licence Information,” online: <cnlopb.ca/wp-content/up loads/maps/eastnl.pdf>.

Ibid.

Supra note 65.

CEAA 2012, supra note 36 , s 8 .

Ibid, s 38 .
} 
Environmental Assessment Agency (CEA Agency) was the responsible authority for activities identified in regulations. This included "[t]he construction, installation and operation of a new offshore floating or fixed platform, vessel or artificial island used for the production of oil or gas." 84

One of the implications of this for any new development project is that the environmental assessment process under the CEAA 2012 and the CNLOPB development plan application approval process under the Accord Act will run separately. While the CEAA 2012 permits agreements to recognize provincial or other environmental assessment processes as duplicating the CEAA 2012 process and creates a process to defer to them, there has been no indication that this will occur in the NL Offshore. Instead, at best the CEA Agency and the CNLOPB may agree to coordinate the environmental assessment and development plan approval processes to the extent possible. This can be seen in the Memorandum of Understanding signed between CEA Agency and the CNLOPB on the conduct of the environmental assessment and development plan approval processes for the proposed Bay du Nord Development Project. In this Memorandum, the parties agreed as follows:

3.2. In order to avoid duplication, the [environmental assessment] and Development Application Review process shall be integrated to the extent possible. In addition, the Agency's [environmental assessment] Report and decision statement shall be used by the C-NLOPB, to the extent possible, in fulfilling the environmental aspects of the Development Application.

3.3. The Agency and the C-NLOPB shall strive to coordinate respective decision making, while adhering to respective legislative timelines. ${ }^{85}$

While attempts at coordination should be commended, this still means Equinor as proponent of the Bay du Nord Project will be entering into two distinct processes for its environmental assessment process and development plan approval process, dealing with the CEA Agency and the CNLOPB, with the best hope being to minimize duplication of processes to the greatest extent possible. This is a long way from the "stand alone public review" touted for the White Rose Project as the benchmark for future project processes. ${ }^{86}$ Another and more pronounced implication of the CEAA 2012 for the NL Offshore has been the experience with exploration activity. The CEAA 2012 combined three changes to fundamentally alter the environmental assessment process for exploratory drilling. The CEAA 2012's removal of the CNLOPB as a responsible authority was combined with the addition of exploratory drilling as a designated project under the regulations under the $C E A A$ 2012 , in the form of " $[\mathrm{t}]$ he drilling, testing and abandonment of offshore exploratory wells in the first drilling program in an area set out in one or more exploration licences issued" by the CNLOPB ${ }^{87}$ The result of these two changes was that exploratory drilling programs which previously had been reviewed by the CNLOPB now require environmental assessments by the CEA Agency. Further complicating matters, the Agency interpreted "in an area" to mean

${ }_{84}$ Regulations Designating Physical Activities, SOR/2012-147, s 11.

85 Memorandum of Understanding between the Canadian Environmental Assessment Agency and the Canada-Newfoundland and Labrador Offshore Petroleum Board on the Integrated Environmental Assessment and Development Application Review of the Bay du Nord Development Project, January 2019, online: <ceaa-acee.gc.ca/050/documents/p80154/126840E.pdf>.

$86 \quad$ White Rose Report, supra note 33 at 2.

87 Regulations Designating Physical Activities, supra note 84, s 10. 
an exploration licence. The result was that the first well drilled in every exploration licence required a full CEAA 2012 environmental assessment, regardless of whether the geographic location, basic, or reservoir had previously been subject to any form of drilling activity.

The result of this has been that the process for obtaining approval to drill has gone from approximately six to nine months under the CNLOPB to over two years with the CEA Agency ${ }^{88}$ New exploration licences issued since 2013 have resulted in six environmental assessment processes for exploratory drilling programs. As of May 2019, four are still in progress. Two were released in April 2019, on average 893 days after the environmental assessment was commenced. ${ }^{89}$

Another new aspect of the CEAA 2012 process, as compared to the CEAA 1992 process, has been the requirement for Indigenous consultation through the process. The CEA Agency in setting out the obligation has referenced the requirements of both the Crown's duty to consult as derived from section 35 of the Constitution Act, $1982^{90}$ and section 5 of the CEAA 2012 as establishing the obligation. ${ }^{91}$ Section 5 of the CEAA 2012 states:

(1) For the purposes of this Act, the environmental effects that are to be taken into account in relation to an act or thing, a physical activity, a designated project or a project are

(c) with respect to aboriginal peoples, an effect occurring in Canada of any change that may be caused to the environment on

(i) health and socio-economic conditions,

(ii) physical and cultural heritage,

(iii) the current use of lands and resources for traditional purposes, or

(iv) any structure, site or thing that is of historical, archaeological, paleontological or architectural significance. $^{92}$

Under the CEAA 2012, through the environmental impact statement guidelines developed for each exploration project, the CEA Agency has required consultation with Indigenous groups throughout eastern Canada. The focus of this consultation has been, at least in part, on the basis of Atlantic salmon migratory routes including the Grand Banks, and as a result Senate Standing Committee on Energy, the Environment and Natural Resources Re: Bill C-69 (28 February 2019) at 3-4, online: $<$ sencanada.ca/content/sen/committee/421/ENEV/Briefs/2019-02-28 C69 NewfndlandLab_Supp_e.pdf $>$ [NL Submission]. Government of Canada, Canadian Impact Assessment Registry, online: <iaac-aeic.gc.ca/050/ evaluations $/ 050$ ?culture $=$ en-CA $>$ at projects 80129 and 80132 [CEA Registry].

90 Being Schedule B to the Canada Act 1982 (UK), 1982, c 11.

91 Letter from the Canadian Environmental Assessment Agency to Husky Oil Operations Ltd re: Additional Information Requirements Regarding Engagement with Indigenous Groups (27 April 2017) at 1, online: <ceaa-acee.gc.ca/050/evaluations/document/118947?culture=en-CA $>$ [Husky Letter] CEAA 2012, supra note 36, s 5. 
Indigenous groups with potential interests in salmon fishing have been included in the consultation obligations. ${ }^{93}$ For example, "following careful consideration of additional information provided to the [CEA] Agency by an Indigenous group and Fisheries and Oceans Canada," Husky Energy has been requested to consult with over 30 Indigenous groups in Newfoundland and Labrador, Nova Scotia, New Brunswick, Prince Edward Island, and Quebec. $^{94}$

These requirements appear to be based on an expansive definition of the scope of the duty to consult and section 5 of the CEAA 2012 for the NL Offshore. There are no cases establishing the scope of the duty to consult in this context, and what little litigation which has occurred in respect of section 5(1)(c) since the CEAA 2012 was passed has not been in relation to defining the scope of its obligations. There is no litigation pending, either by proponents or by Indigenous groups, challenging the CEA Agency's interpretation and policies for the environmental assessments underway in the NL Offshore. The proponents engaged in the environmental assessment process have been complying with the CEA Agency requirements and engaging in the requested consultation activities. As a result the expectation is that such Indigenous consultation will continue to be a requirement under the CEAA 2012.

Perhaps not surprisingly, this development is entirely a new issue in the Newfoundland offshore (as distinct from the Labrador offshore area, where the need for Indigenous consultation has been acknowledged for some time). None of the projects had any formal element of Indigenous consultation in either their development plan application review processes or their environmental assessment processes. No report identified Indigenous consultation or the consideration of Indigenous community rights or issues in making its decisions. Neither the Hibernia Project nor Terra Nova Project environmental assessment reports, nor the Report of the Commissioner on the White Rose Project or the Hebron Decision Report make any reference to Indigenous consultations, or have any consideration of Indigenous rights or concerns included in the decision or recommendations for any project. A review of the detailed environmental and decision reports indicate that while presentations may have been received from Indigenous groups on public consultation sessions, they were presented without special status or consideration but as members of interested communities and community groups. ${ }^{95}$

This is not to say that the CNLOPB has operated without any consideration of Indigenous issues. The CNLOPB has been involved in consultation with the Indigenous groups in Labrador as it moves to a strategic environmental assessment of areas off the Labrador coast in anticipation of a future call for bids. ${ }^{96}$ However, the CNLOPB's position appears to differ

93 Letter from the Canadian Environmental Assessment Agency to Statoil Canada Ltd re: Information Requests Related to the Environmental Impact Statement Round 1 (Part 1) (13 March 2018), online: $<$ ceaa-acee.gc.ca/050/evaluations/document/122047>.

$94 \quad$ Husky Letter, supra note 91 at 5.

95 There is no indication of Indigenous consultation having occurred in the environmental assessment process for existing projects, other than potential references to participation as part of general community involvement. See e.g. the Hibernia EA, supra note 24 at 54 (see reference to Newfoundland Federation of Indians presentation on 17 October 1985). The Terra Nova Report makes no reference (CNLOPB, Decision 97.02 re: Application for Approval of Terra Nova Canada-Newfoundland Benefits Plan and Terra Nova Development Plan (St. John's, NL: CNLOPB, 1997), online: <cnlopb.ca/wpcontent/uploads/news/d97_02e.pdf $>$ ).

96 CNLOPB, 2017-18 Annuāl Report (St John's, NL: CNLOPB, 2018) at 13, online: <cnlopb.ca/wpcontent/uploads/ar2018e.pdf>. 
from the CEA Agency in that it does not require Indigenous consultation in respect of decisions under its jurisdiction in respect of the Newfoundland offshore. For example, the CNLOPB does not require Indigenous consultation in its environmental assessment of seismic programs, which (as they are not a prescribed activity under the CEAA 2012) remain within the CNLOPB's assessment authority. The CNLOPB has acknowledged the issue, and has stated it will continue to consider the issue in consultation with the federal and provincial governments. $^{97}$

\section{BILL C-69: THE UNKNOWN}

Any discussion of the environmental assessment processes facing potential future development projects has to discuss the potential implications of Bill C-69. As of March 2019, the Bill was still under review by the Senate, which has referred it to committee and is holding hearings on the proposed legislation. ${ }^{98}$

Bill C-69 is an omnibus revision to the environmental assessment process in Canada. Structurally it would replace the CEAA 2012 with a new Impact Assessment Act ${ }^{99}$ and replace the National Energy Board Act ${ }^{100}$ with a new Canadian Energy Regulator Act, ${ }^{101}$ with corresponding changes to the related agencies. Substantively, it involves a significant expansion of the scope of assessments which would be carried out, as well as the aggregation of all assessments into the new Impact Assessment Agency, the successor to the CEA Agency.

A full review of the scope of the potential changes under Bill C-69, and the concerns these changes have raised generally for what would be impact assessments is well beyond the scope of this article. ${ }^{102}$ In addition to the concerns that have been expressed from a number of sources in Canada, there are points which have been of significant concern to participants in the NL Offshore and to the Province in respect of potential future development projects. One concern flagged by the Canadian Association of Petroleum Producers (CAPP) and the Province of Newfoundland and Labrador in submissions to the Senate was the mandatory requirement for a review panel. ${ }^{103}$ Section 43 of the proposed Impact Assessment Act provides that for a designated project, any physical activities that are governed by the Accord Act (in other words, regulated by the CNLOPB) automatically has to be referred to a review

$97 \quad$ Ibid at 15

Senate of Canada, "Standing Committee on Energy, the Environment and Natural Resources," online: $<$ sencanada.ca/en/committees/enev/42-1>.

Bill C-69, supra note 65, Part 1.

Ibid, Part 1, s 9.

Ibid, Part 2.

For example, there have been extensive presentations to the Senate Committee on the implications for exploratory drilling activity in the NL Offshore under Bill C-69, including the potential for even greater delays than experienced under the CEAA 2012 and the mandatory review panel requirement (letter from Canada's Oil and Natural Gas Producers to the Senate Standing Committee on Energy, the Environment and Natural Resources, (15 February 2019), online: <sencanada.ca/content/sen/committee/421/ENEV/ Briefs/2019-02-15_ENEV_BillC-69_BRF_CAPP_e.pdf $>$ [CAPP Letter]; Newfoundland and Labrador Oil \& Gas Industries Association (NOIA), Submission of the Newfoundland and Labrador Oil \& Gas Industries Association (Noia) to the House of Commons Standing Committee on Environment and Sustainable Development regarding Bill C-69, (St John's, Nfld: NOIA), online: <www.noia.ca/Portals/0/ Communications/General\%20and\%20Mics/House\%20of\%20Commons\%20on\%20Bill\%20C-69\%20 Final\%20Submission\%20-\%20180406_1.pdf>).

103 Government of Newfoundland and Labrador, News Release, "Provincial Government Presents Submission on Bill C-69 to Senate," (28 February 2019), online: <releases.gov.nl.ca/releases/2019/ exec/0228n04.aspx>; see also NL Submission, supra note 88. 
panel, the highest level of review possible under the Impact Assessment Act. ${ }^{104}$ Further, the composition of that review panel requires representatives from the CNLOPB, but it is mandated that the CNLOPB representatives cannot be the majority of the panel. ${ }^{105}$ As noted by CAPP, this mandatory reference prevents any ability to adjust or calibrate the level of review to the activity in question: "As a result, the [Impact Assessment Act] provides no means to align the scale and type of assessment process to the particular designated offshore project." 106 In presentations to the Senate, it was noted that the White Rose and Hebron Projects were never submitted to a panel review.

Another concern raised has been with the level of discretion Bill C-69 provides the federal government to determine that a project will not proceed, and how that authority conflicts with the joint management provisions enshrined in the Atlantic Accord. Under the proposed Impact Assessment Act, the determination as to whether the "adverse effects [or] within federal jurisdiction — and the adverse direct or incidental effects — that are indicated ... are ... in the public interest" rests with the federal Minister or the federal cabinet. ${ }^{107}$ This effectively gives the federal government a veto over any offshore physical activity, including (but as set out above not necessarily restricted to) development projects. This veto is independent of and outside of the joint management arrangement agreed between the federal and provincial governments in the Atlantic Accord. While this power also existed under previous environmental assessment regimes, the expansion of the concept of the "public interest" under the Impact Assessment Act has significantly increased the scope of this power. The Province, in its presentation to the Senate, raised this issue and the need to respect the joint management regime of the Atlantic Accord. ${ }^{108}$

For Newfoundland and Labrador's past offshore projects, the environmental assessment process was at least a certainty, even if the results and recommendations coming out of the environmental assessment process were not. It does not appear that future developments in the NL Offshore will enjoy this level of certainty for some time. At this point, the uncertainty is twofold - the uncertainty both about which regime will apply, and also what the scope, requirements, and timeframe will be under either regime, if the CEAA 2012 continues or if some form of Bill C-69 is ultimately passed.

\section{F. Difference 6: The Royalty Regime}

In 2017 the Province introduced regulations to replace the generic royalty regime set out in the Royalty Regulations, 2003. Referred to as the Offshore Oil Royalty Regulations, ${ }^{109}$ this new regime will apply to all future projects. It will not affect Newfoundland and Labrador's past offshore projects, which will continue to be subject to the contractual and regulatory requirements under the Royalty Regulations, 2003 described above.

This regime materially changes aspects of the previous royalty regimes for future development projects. While the concept of basic and incremental royalties has been

Bill C-69, supra note 65, Part 1, s 5. 
retained, the calculations of both are now tied to calculation of a "recovery factor." The "recovery factor" is a ratio of the cumulative net revenue over cumulative costs. ${ }^{110}$ It is calculated, as of a given month, as the aggregate of the cumulative gross sales revenue and incidental revenue less cumulative transportation costs, basic royalty paid, and net royalty paid, then divided by the sum of the cumulative recognized pre-development, capital, and operating costs. The effect is a ratio that, when the cumulative net revenues received by an interest owner on a project equals the cumulative costs on the project as of a certain date, the calculation returns a value of 1 . It is similar to the calculation of payouts under the previous royalty regimes, but with two significant differences: there is no return allowance or other recognition of the time value of money, and there is only one such calculation formula for all purposes under the new regime.

While the concept of a basic royalty charged as a percentage of gross revenue has been retained, and at similar rates of between 1 percent and 7.5 percent, the use of the recovery factor means the escalation between these amounts is entirely different. Where the Hibernia Project Royalty Agreement or the Royalty Regulations, 2003 provided for rate escalation based either on cumulative production of barrels or elapsed time, the OORR uses the recovery factor. Basic royalty is 1 percent between first oil and $\mathrm{R}<0.25 ; 2.5$ percent when $\mathrm{R}$ is between 0.25 and $1 ; 5$ percent between 1 and 1.25 ; and 7.5 percent once $\mathrm{R}$ exceeds $1.25 .^{111}$

The same approach is applied to the incremental royalties. Once the return allowance factor hits 1 , at the same time 5 percent basic royalty becomes payable, incremental royalties are also payable. From a recovery factor between 1 and 3 (meaning the period between the moment the project recovers 100 percent of its cumulative costs and the moment it recovers 300 percent of its cumulative costs to a particular date) the incremental royalty rate is calculated on a straight line progression between 10 percent and 50 percent. For example, at a recovery factor of 2 (or 200 percent recovery of cumulative costs), the incremental royalty will be 30 percent (half way between 10 percent and 50 percent). ${ }^{112}$ Once the recovery factors hits 3 or higher, the 50 percent net royalty applies. This rate is higher than any tier of incremental royalty in any of the existing project fiscal regimes.

Perhaps more consequential in the longer term are the process changes that move the administration of the regime towards being a regulatory structure as opposed to a negotiated contractual regime. For example, some costs previously subject to cost criteria, such as predevelopment costs, are now subject to Ministerial discretion to determination of fair market value. ${ }^{113}$ More significantly, arbitration is no longer available as a means of dispute resolution. In the arbitration structures that have existed for parties to date, such as under the Royalty Regulations, 2003, decisions by the relevant department and Minister on a number of fundamental issues relating to the qualification of costs and calculation of royalties payable were subject to being challenged by arbitration. ${ }^{114}$ In such arbitrations, the interest owners and the Province appeared as equal parties to the dispute. The arbitration process was 
adjudicated as a commercial dispute between equal parties to a contractual relationship. Judicial review was available but not used to challenge a departmental or ministerial determination at first instance, but instead to challenge the arbitrator's decision. ${ }^{115}$

Under the OORR, the arbitration option has been eliminated. Decisions by the Minister are no longer subject to arbitration. Further, a privative clause provides that such a decision is expressly final and not subject to appeal. ${ }^{116}$ Instead, the only avenue for review by a proponent would be judicial review "on a question of law or jurisdiction." 117 The project proponent taking such an action is facing an entirely different legal context than in a commercial arbitration of the Minister's decision under the previous regime. The critical issues in such a judicial review will be the standard of review adopted by the court and the degree of deference the Minister is granted in consideration of the decision involved. This will be determined in future litigation, but the privative clause in section 85 makes it significantly likely the Minster's decision would be afforded deference and as a result the standard of review of the decision would be reasonableness. The Supreme Court of Canada has recently spelled out on a practical level what a standard of reasonableness means:

\footnotetext{
In its application, reasonableness review recognizes the legitimacy of multiple possible outcomes, even where they are not the court's preferred solution. In reasonableness review, the reviewing court is concerned mostly with the existence of justification, transparency and intelligibility within the decision-making process and with determining whether the outcome falls within a range of possible, acceptable outcomes that are defensible in respect of the facts and law. When applied to a statutory interpretation exercise, reasonableness review recognizes that the delegated decision maker is better situated to understand the policy concerns and context needed to resolve any ambiguities in the statute. Reviewing courts must also refrain from reweighing and reassessing the evidence considered by the decision maker. ${ }^{118}$
}

In other words, to succeed in challenging a Minister's decision under the OORR, a project owner will now be engaged in an administrative law process. It should anticipate that it would now have to demonstrate that the Minister's interpretation was unreasonable under the legislation. It would not be enough for the interest owner to establish that its interpretation is more reasonable that the Minister's interpretation, an argument that likely would have succeeded in arbitration. Now, if the Minister's decision is found to be reasonable, even if not the most reasonable or even if not as reasonable as the interest owner's, it will not be overturned on judicial review.

This is a long way from the arbitration processes which remains in place for the Projects. It restructures the power relationship between the Province as royalty owner and the interest owners into a regulatory one. This is maybe neither surprising nor inappropriate, particularly given that the increase in offshore activity may require the Province to move into more of an administrative role, but it does mark a significant change in the relationship for future developments from that enjoyed, and that will continue to be enjoyed, by the Projects.

There may be a means for proponents of a future project to return to the status quo on this issue, and other changes presented by the OORR. Section 33 of the PNG Act still applies to

Canada (Canadian Human Rights Commission) v Canada (Attorney General), 2018 SCC 31 at 233-34. 
the OORR, and provides the ability for the Province to negotiate contractual arrangements which override these regulations. However, there is no indication that the Province intends at this point to use such provisions. The Province has indicated that the new regime will be the regime for future developments, implying that it is less receptive than in the past to bespoke negotiated variations on the regime for a particular project. ${ }^{119}$ While the press release in respect of the Bay du Nord announcement on 26 July 2018 stated that the project would be the "first project to be negotiated under Newfoundland and Labrador's generic oil royalty regulations," no details respecting the any negotiated aspects of the royalty regime have been made public. ${ }^{120}$

\section{UNited NATIONS CONVENTION ON THE LAW OF THE SEA}

Even with the significant changes of the OORR, when it comes to the royalties issues facing future development projects, it is not the most significant royalty concern for future development projects. Instead, that distinction should be reserved for the application of an entirely separate royalty regime in the NL Offshore as a result of the United Nations Convention on the Law of the Sea. ${ }^{121}$

Originally agreed in 1982, and ratified by Canada in 2003, UNCLOS established and confirmed Canada's authority over the development of the petroleum resources on the Grand Banks and the continental shelf. ${ }^{122}$ It did this through two separate authorities. First, it established a 200-nautical-mile exclusive economic zone (EEZ) for all member states, which provided sovereign authority over the exploitation of both living and non-living seabed resources of the adjacent state. ${ }^{123}$ It also confirmed the exclusive authority for those coastal states to exercise sovereign authority over the development of seabed resources to the limit of the continental shelf, in that anyone wishing to explore and develop in such areas is required to do so with the consent and on the terms set by the adjacent coastal state. ${ }^{124}$

While Canada claimed jurisdiction and authority over the area pre-1982, UNCLOS ratified this authority as international law. The EEZ declaration is the basis for a number of authorities Canada exerts over the oceans, including but not restricted to powers set out under the Fisheries Act and the Oceans Act. ${ }^{125}$

The royalty issues arise in the exploitation of seabed resources on the continental shelf outside of the EEZ. There are only a few locations in the world where the continental shelf extends beyond the $200 \mathrm{~nm}$ limit; the Grand Banks offshore Newfoundland and Labrador are the largest such locations in the world. ${ }^{126}$ In these locations, while article 77 of UNCLOS

119 "Newfoundland and Labrador Introduces New Royalty Regime for Offshore Oil," Financial Post (2 November 2015), online: < business.financialpost.com/commodities/energy/newfoundland-and-labradorintroduces-new-royalty-regime-for-offshore-oil $>$.

120 "New Frontier," supra note 63.

121 10 December 1982, 1833 UNTS 397 (entered into force 16 November 1994), online: <un.org/depts/los/ convention_agreements/texts/unclos/unclos_e.pdf> [UNCLOS].

Ibid.

Ibid, art 56.

Ibid, art 77.

Wylie Spicer, "Canada, the Law of the Sea Treaty and International Payments: Where Will the Money Come From?" (2015) 8:31 U Calgary SPP Research Papers at 8, online: <papers.ssrn.com/sol3/papers. cfm?abstract_id=2658802>. 
confirms and confers the jurisdiction upon coastal states to control development of subsoil resources, article 82 of UNCLOS imposes a royalty obligation upon the coastal state. Article 82 requires that a royalty on production from these areas be submitted to the International Seabed Authority (ISA) established under UNCLOS. That royalty commences after five years of production at 1 percent, and increases 1 percent annually until year 12, after which time it remains at 7 percent for the life of the field. ${ }^{127}$

A significant number of the areas currently held under exploration licences in the NL Offshore are located either straddling, or entirely outside, Canada's $200 \mathrm{~nm}$ limit. Of the eight exploration projects that were undergoing environmental assessment for exploratory drilling in the NL Offshore (two of which were subsequently released as set out above), all eight involve exploration licences that either intersect, or lie entirely outside, of the $200 \mathrm{~nm}$ limit. The site of the potential Bay du Nord development is well outside the $200 \mathrm{~nm}$ limit. As such, if it proceeds it will trigger article 82 obligations, and may be the first project in the world to do so. ${ }^{128}$

At this point, given it has never been applied, this royalty regime is characterized by a number of uncertainties. The first is the ISA and its expectations in dealing with issues relating to the calculation, payment, and administration of this royalty. It has done preliminary policy work to acknowledge the issues of the administration of the royalty, and the requirements for a relationship with a coastal state in question, to the point of developing a working draft agreement that the IAS would have with the relevant coastal state. ${ }^{129}$ The preliminary documents have identified the expectation that the ISA would be the "receiver" as opposed to the "collector" of payments, and acknowledges that this creates the requirement for both transparency and information sharing with the relevant coastal state in the administration of the regime. ${ }^{130}$ There is no indication, however, that these issues have been resolved or that the draft agreement has been finalized. Any discussions which may have been ongoing between the authority, Canada and the Province on this issue have not been made public.

The second uncertainty is the calculation of the royalty itself. Perhaps as to be expected with an international treaty of the scope of UNCLOS, article 82 is a model of brevity in the description of a royalty regime:

Article 82 Payments and contributions with respect to the exploitation of the continental shelf beyond 200 nautical miles

UNCLOS, supra note 121 , art 82.

See Rowland J Harrison, "Offshore Oil Development in Uncharted Legal Waters: Will the Proposed Bay Du Nord Project Precipitate Another Federal-Provincial Conflict?” (2018) 6:4 Energy Regulation Q, online: <energyregulationquarterly.ca/articles/offshore-oil-development-in-uncharted-legal-waters-willthe-proposed-bay-du-nord-project-precipitate-another-federal-provincial-conflict>. Ibid at 19 . 
1. The coastal State shall make payments or contributions in kind in respect of the exploitation of the non-living resources of the continental shelf beyond 200 nautical miles from the baselines from which the breadth of the territorial sea is measured.

2. The payments and contributions shall be made annually with respect to all production at a site after the first five years of production at that site. For the sixth year, the rate of payment or contribution shall be 1 per cent of the value or volume of production at the site. The rate shall increase by 1 per cent for each subsequent year until the twelfth year and shall remain at 7 per cent thereafter. Production does not include resources used in connection with exploitation.

3. A developing State which is a net importer of a mineral resource produced from its continental shelf is exempt from making such payments or contributions in respect of that mineral resource.

4. The payments or contributions shall be made through the Authority, which shall distribute them to States Parties to this Convention, on the basis of equitable sharing criteria, taking into account the interests and needs of developing States, particularly the least developed and the land-locked among them. $^{131}$

The only certainty is that a royalty will exist. Other than that, these provisions raise a number of questions in the administration of the regime. The ISA has identified that the terms "resource," "all production," "value," "volume," "site," "payments," "contributions in kind," and "annually" all require some further level of definition in order for the royalty to be able to be practically applied. ${ }^{132}$ As noted by the late Wylie Spicer, how these terms are ultimately defined could have significant impacts upon the magnitude and therefore funding obligations of meeting the article 82 commitment. ${ }^{133}$ The only issue upon which the ISA appears to have reached a conclusion was in respect of whether the royalty will be paid in currency or taken and delivered in kind. Given the complexities related to potentially assuming responsibility for the delivery and transportation of petroleum around the world, the recommendation in 2012 of the International Workshop on article 82 was that coastal states "should be encouraged to opt only for payments in the interests of simplicity and efficiency implementation." 134

A third uncertainty is who will be paying the article 82 royalty to the ISA, even once the details respecting its calculation are resolved. As a royalty, it would ordinarily be assumed that the project proponent would be the party paying the royalty on its production. ${ }^{135}$ However, at an eventual 7 percent value of production, the amount involved represents a material portion of the fiscal value of an offshore development project. The Province's position has been that it would not accept paying this amount from its royalty revenue, or having any such payments offset from the royalties it would be collecting. As an example of this, the royalty regime established in 2017 under the OORR does not contain any

UNCLOS, supra note 121 , art 82.

Technical Study No 12, supra note 129 at 20, 62.

Spicer, supra note 125 at 17.

Technical Study No 12, supra note 129 at 24, 32.

OORR, supra note 109, s 4. 
adjustment or deduction for any payments of an UNCLOS royalty by an interest owner. ${ }^{136}$ Instead, the Province has consistently maintained that payment of this royalty is a responsibility of Canada, as a signatory to UNCLOS ${ }^{137}$ Equinor, as the proponent of the potential Bay du Nord project, and as such also potentially the first proponent in the world that will have article 82 apply to its project, has not volunteered to pay the royalty; they instead appear to be affirming the Province's position that "UNCLOS is an obligation of the government of Canada." ${ }^{138}$ Canada has only stated that it is evaluating its obligations but has made no indication it is prepared to assume liability for the royalty. ${ }^{139}$

At this point, this is a political issue. The only good news is that if the Bay du Nord project proceeds, at some point most of these issues will have to be resolved. Such resolution should apply to all future projects, meaning that as they proceed they will enjoy resolution of at least part of this uncertainty.

\section{So Where Does That Leave Us?}

There is no question that new development projects in the NL Offshore are facing a more complex regulatory environment than the ones which past projects faced as they moved to development. However, this should not necessarily be seen as an insurmountable obstacle. At the risk of quoting the great philosopher Billy Joel, "the good ole days weren't always good, and tomorrow ain't as bad as it seems."

In some ways it could be said future developments are facing a more certain future than that which faced past projects, in recognition of the degree to which those original projects broke entirely new legal, economic, social, and regulatory ground. The uncertainty and challenges which faced the Hibernia Project, in creating an entirely new industry, cannot be minimized in hindsight.

The past 20 years have also demonstrated that with respect of the issues in the offshore that are not undergoing significant change, the existing systems are robust. A few of the features in the NL Offshore (other than the weather and icebergs, which one may argue are in fact changing) persist. One is the underlying licencing and regulatory regime of the CNLOPB. The exploration, significant discovery, and production licence system enshrined in the CNLOPB's legislation has persisted since 1987, and there is every indication it will remain for future developments based on the current regimes.

Further, while various aspects of the regime may be changing, the system for implementation of a royalty regime by the Provincial government has also shown itself to be reliable. Any issues that may occur with the details as the OORR are implemented will occur within a legal framework that underpins both the existing and new regimes and can be

Ibid, ss 63(1)(c) and (d) expressly disallow the inclusion of royalties or taxes as a deduction against eligible costs in the calculation of royalties or the recovery factor.

Rob Antle, "UN Could Cash in NL Oil Project - But Questions Linger over Who Would Pay," CBC (27 July 2018), online: <cbc.ca/news/politics/ottawa-bay-du-nord-unclos-dwight-ball-payments-1.4763 $436>$.

Ibid.

Ibid.

Billy Joel, "Keeping the Faith,” An Innocent Man (Columbia Records,1983). 
relied upon by future developments. The same can also now be said of the equity interests held by Nalcor Oil \& Gas; it has shown itself to be a reliable project partner and both its requirement for participation and its conduct once engaged can now be reliably predicted by future project proponents.

What is obvious, however, is that the scope of the legal and regulatory context for development is expanding exponentially beyond that which was enjoyed by the projects. Through the changes to the CEAA 2012, and even more so if Bill C-69 is passed, the federal government is increasing its direct involvement in the development of the NL Offshore, and the involvement of large numbers of other groups and interests, to an extent that did not exist for the projects. This complexity is only increased by the arrival of the ISA, and further with the potential interaction of the ISA, the federal government, and the province.

Yet while there is significant uncertainty respecting what the requirements upon future developments will be, some elements of that uncertainty are functions of this point in time, and will decrease in the near future. The uncertainty respecting the environmental assessment processes will be lessened once the fates of the CEAA 2012 and Bill C-69 are determined. The uncertainty respecting the UNCLOS royalty will be reduced over time, perhaps as the Bay Du Nord development proceeds and necessarily resolves many of these issues for subsequent projects, in much the same role the Hibernia Project originally played. Until that point, future development projects may not differ that much from the past projects in one respect: while the causes may be different, patience is a virtue that will still be required.

As a result, while there are lessons to learn from the projects, it is now clear that as proponents move forward with discussions on new developments, the change in context from that of the earlier projects is so significant that the next potential development projects in the offshore can be described as belonging to a new, second generation of developments.

\section{ADDENDUM}

This article was originally prepared and submitted to the Canadian Energy Law Foundation in March 2019. Since it was originally finalized, a number of changes have occurred to the referenced information. References to the cumulative production amounts of the Projects have been updated. However, while an amended version of Bill C-69 was adopted and passed by Parliament in June 2019, and came into force on 29 August 2019, the discussion of CEAA 2012 and Bill C-69 has not been updated as this would have necessitated significant modification to the original article. For reference, the amended version of the legislation that was proclaimed did not include amendments as requested in response to the NL Offshore-specific concerns noted above. The CEAA2012 will continue to have relevance in the NL Offshore as the proposed Bay du Nord project will continue to be evaluated under CEAA 2012, as well as the exploratory drilling projects that were in progress or accepted for review under CEAA 2012 before 29 August 2019. The Impact Assessment Act, and the accompanying changes implemented with the proclamation of Bill C-69, will apply to any future new exploration or development projects. 